\title{
Surprises from a cardiac 5-HT 4 TG mouse: spontaneous atrial arrhythmias by endogenous 5-HT of atrial origin? Different mechanism of arrhythmias through $5-\mathrm{HT}_{4}$ receptors and $\beta$-adrenoceptors?
}

\author{
Alberto J. Kaumann \\ Published online: 31 January 2013 \\ (C) Springer-Verlag Berlin Heidelberg 2013
}

$5-\mathrm{HT}_{4}$ receptors of human myocardium mediate cardiostimulant effects of 5-hydroxytryptamine (5-HT, serotonin) mainly through the $\mathrm{G}_{\mathrm{s}}$ protein $\rightarrow \mathrm{cAMP} \rightarrow \mathrm{PKA}$ pathway. Several $5-\mathrm{HT}_{4}$ receptor splice variants are expressed in human heart but functional differences have not yet been detected (Reviewed in Kaumann and Levy 2006). 5-HT does not only increase myocardial force and hasten relaxation (Kaumann et al. 1990; Sanders and Kaumann 1992; Brattelid et al. 2004), but can also elicit arrhythmic contractions in atrial trabeculae (Kaumann and Sanders 1994) and myocytes (Sanders et al. 1995) as well as in ventricular trabeculae (Brattelid et al. 2004). It has been proposed that 5-HT can initiate atrial fibrillation (Kaumann 1994) and facilitate arrhythmias in patients with ischaemic heart disease (Brattelid et al. 2004). Chronic treatment of patients with $\beta$-blockers potentiates the inotropic effects of 5-HT in atrial trabeculae and myocytes (Sanders et al. 1995). 5-HT increases the L-type $\mathrm{Ca}^{2+}$ current $\left(\mathrm{I}_{\mathrm{Ca}, \mathrm{L}}\right)$ in human atrial myocytes in a PKA-dependent manner (Ouadid et al. 1992). Chronic treatment of patients with $\beta$-blockers potentiates the effects of 5-HT on $\mathrm{I}_{\mathrm{Ca}, \mathrm{L}}$ and arrhythmic activity of atrial myocytes (Pau et al. 2003). 5-HT causes also cardiostimulation in porcine heart (Kaumann 1990; Parker et al. 1994; Brattelid et al. 2004), but not in other non-primate species, at least under physiological conditions. Arrhythmias, probably mediated through 5- $\mathrm{HT}_{4}$ receptors, have also been reported in porcine atrium (Rahme et al. 1999). Rat ventricular 5-HT 4 receptor expression and function is induced in rats with ischaemic heart failure but not in normal rats (Qvigstad et al.

A. J. Kaumann $(\triangle)$

Department of Pharmacology, University of Murcia, Murcia, Spain e-mail: ajk41@hermes.cam.ac.uk
2005), plausibly by reactivating a phenotype resembling late foetal development (Brattelid et al. 2012).

Gergs et al. (2010) overexpressed human 5-HT 4 a receptors in the heart of mice that normally do not express functional cardiac $5-\mathrm{HT}_{4}$ receptors. In these transgenic mice 5-HT produced sinoatrial tachycardia, increases in ventricular $\mathrm{I}_{\mathrm{Ca}, \mathrm{L}}$ and $\mathrm{Ca}^{2+}$ transients, positive inotropic and lusitropic effects in ventricle, associated with phosphorylation of phospholamban (PLB) at Ser16 in ventricular myocytes and Thr 17 in perfused working hearts. These features resemble the pharmacology of $5-\mathrm{HT}_{4}$ receptors in human heart. 5-HT, but hardly isoprenaline, also caused arrhythmic $\mathrm{Ca}^{2+}$ transients in venricular myocytes from TG hearts. Interesting, in isolated hearts from these TG hearts Gergs et al. (2010) demonstrated episodes of spontaneous polymorphic atrial arrhythmias in the absence of exogenous 5HT that resemble shortlasting episodes of atrial fibrillation.

In an additional report of Gergs et al. (2013) in the present issue of Naunyn-Schmiedeberg's Archives of Pharmacology, the authors studied the effects of 5-HT on paced left atria and spontaneously beating right atria from their TG mouse. As expected, 5-HT produced sinoatrial tachycardia and increases in left atrial force, left atrial arrhythmias, phosphorylation of PLB at Ser16 and arrhythmias, which were antagonised by $5-\mathrm{HT}_{4}$ receptor blockers. Surprisingly and interesting, however, 19 of 21 paced left atria spontaneously developed arrhythmias in the absence of exogenous 5-HT that were blocked by GR113808, consistent with mediation through $5-\mathrm{HT}_{4}$ receptors. The spontaneous arrhythmias were reported to reappear after washout of GR113808. In contrast and interesting, (-)-isoprenaline (1 $\mu \mathrm{M})$ hardly elicited left atrial arrhythmias (1 of 26 in TG vs 1 of 16 in wild-type (WT) mice) (Dr. U. Gergs, personal communication). Gergs et al. (2013) also measured the 5HT plasma levels and 5-HT content of heart tissues but 
found no differences between TG and WT mice. Interesting, reserpine caused a $83 \%$ decrease of heart 5-HT levels in TG mice and this was associated with only one case of spontaneous arrhythmias in 8 left atria, suggesting an involvement of endogenously released 5-HT.

If spontaneous arrhythmic contractions in paced left were produced by a hypothetical release of endogenous 5-HT, where did it come from? Plasma and platelet-derived 5-HT can be excluded because the atria were paced in a modified Tyrode's solution. Human ventricular myocardium contains 5-HT (Sole et al. 1979), at least in part localized in cardiac ganglia which may synthesize 5-HT because tryptophan hydroxylase was also found (Singh et al. 1999). Small amounts of 5-HT have also been detected in human right atrium (Pönicke et al. 2012). In human atrium, 5-HT can be captured by sympathetic nerve endings and be released with field stimulation as a false neurotransmitter to increase contractility through activation of myocardial $5-\mathrm{HT}_{4}$ receptors (Fig. 1). The origin of endogenous 5-HT for this mechanism would conceivably come from aggregating platelets (Kaumann 1994). Ventricular 5-HT is also produced in hamster hearts (Sole et al. 1979). Genetic knock-out of the isoform 1 of tryptophan hydroxylase decreases cardiac 5-HT levels and for unknown reasons causes cardiac hypertrophy and heart failure (Côté et al. 2003). Evidence for 5-HT levels, as well as 5-HT synthesis and metabolism, was recently provided for ventricular myocytes of WT mice ((Pönicke et al. 2012). Taken together, 5-HT is present in the heart, but mechanisms of release are still unknown. Furthermore, the hypothesis of 5HT release would have to be restricted only to spontaneous arrhythmias since basal heart rate is unchanged in TG compared to WT mice and because the increased basal force in TG was only non-significantly reduced by GR113808.

An alternative mechanism for the spontaneously arrhythmias in both left and right atria of the TG mice (Gergs et al. 2010, 2013), which cannot completely be discarded, is that the conformational change of the overexpressed $5-\mathrm{HT}_{4}$ receptors allows spontaneous coupling of the receptors to biochemical cascades responsible for the arrhythmias. Constitutive 5- $\mathrm{HT}_{4}$ receptor activity has been demonstrated at a recombinant $5-\mathrm{HT}_{4}$ receptor splice variant, transfected into HeLa cell, and GR113808 was an inverse agonist (Vilaró et al. 2002). Constitutive $5-\mathrm{HT}_{4}$ receptor activity is, however, unlikely to occur because the reserpineinduced depletion of 5-HT prevented the spontaneous arrhythmias. On the other hand, in addition to the facilitation of $5-\mathrm{HT}_{4}$ receptor-mediated cardiostimulation, constitutive activity cannot entirely be ruled out, in clinical (Brattelid et al. 2004) and experimental heart failure of ischaemic origin (Qvigstad et al. 2005). A more compelling source 5-HT would come from platelets aggregating against a damaged atrial wall (Kaumann 1994). These hypothetical mechanisms await experimental verification, especially to clarify mechanisms for the slight improvement of clinical (Kjekshus et al. 2009) and experimental heart failure (Birkeland et al. 2006) observed under chronic treatment with a $5-\mathrm{HT}_{4}$ receptor antagonist.

5-HT increases atrial force and hastens relaxation, consistent with PKA-dependent phosphorylation of PLB and troponin I (Kaumann et al. 1990). Correspondingly, Gergs et al. (2009) provided evidence for the PKA-dependent phosphorylation of PLB at Ser16 and of troponin I in human atrium. In addition, they also demonstrated phosphorylation of PLB at Thr17, not a substrate for PKA but a substrate for calcium calmodulin kinase II (CaMKII). In hearts of 5-HT 4 TG mice, but not WT mice, 5-HT also increased the phosphorylation of PLB both at Ser16 and Thr 17 (Gergs et al. 2010). Furthermore, basal phosphorylation of PLB at Thr17 in the absence of exogenous 5-HT in TG mice was increased in the ventricle of perfused hearts from TG mice and reduced by a 5 $\mathrm{HT}_{4}$ receptor antagonist to levels of WT mice. Gergs et al. (2010) thought that this evidence indicated that the spontaneous arrhythmias may be due to activation of CaMKII in the hearts of TG mice. This interesting suggestion is in line with a report by Neef et al. (2010) of increased CaMKII expression and CaMKII-dependent phophorylation of ryanodine (RyR2) channels at Ser2814 in chronic atrial fibrillation (AF). The phosphorylation of RyR2 increased cytosolic $\mathrm{Ca}^{2+}$ levels, attributed to an increased $\mathrm{Ca}^{2+}$ leak from the sarcoplasmic reticulum, thereby facilitating arrhythmias that could trigger or maintain AF (Neef et al. 2010).

Unfortunately, Gergs et al. (2013, this journal) did not measure phosphoylation of PLB at Thr 17 in left atria of TG mice that developed spontaneous arrhythmias. Furthermore, it is unknown whether 5-HT alters the function of CamKII not only in TG left atria but also in human atrial myocardium from patients with chronic AF. It appears actually unlikely that 5HT-induced activation of CaMKII is increased in chronic AF because the electrophysiological and arrhythmogenic effects of 5-HT are reduced in human atrial myocytes (Pau et al. 2007). These queries need to be investigated.

Gergs et al. (2013) did not succeed in assessing the density of $5-\mathrm{HT}_{4}$ receptors in $\mathrm{TG}$ myocardium. The receptor density in TG atrium was probably considerably higher than the low density of human atrial $5-\mathrm{HT}_{4}$ receptors (3.7 fmol.mg ${ }^{-1}$ Kaumann et al. 1996). The inotropic intrinsic activity of 5-HT was nearly as high as the intrinsic activity of (-)-isoprenaline, while in human atrium intrinsic activity for 5 -HT was between $1 / 2$ and $2 / 3$ that of (-)-isoprenaline (Kaumann et al. 1990). A relatively high density of 5$\mathrm{HT}_{4}$ receptors in TG atrium would also explain the high incidence of spontaneous arrhythmias mediated through these receptors, regardless of whether the arrhythmias were due to endogenous 5-HT or constitutive receptor activity.

The incidence of experimental arrhythmias is lower for 5HT through human atrial $5-\mathrm{HT}_{4}$ receptors than for 
a

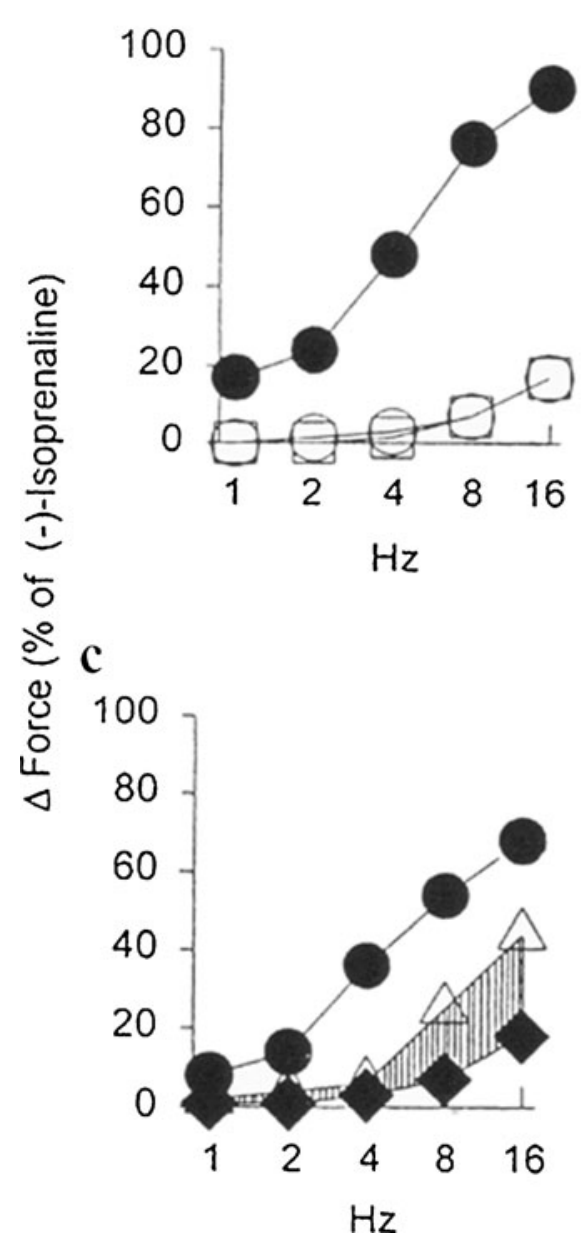

Fig. 1 Capture of 5-HT by nerve endings, released by field stimulation and interaction with $5-\mathrm{HT}_{4}$ receptors. Results from four trabeculae of a right-atrial appendage from a 50 year old male patient undergoing coronary bypass surgery. Three successive curves relating field-stimulation frequency (in $\mathrm{Hz}$ ) to contractile force. Increases in contractile force were expressed as \% of the increase in force by (-)-isoprenaline $(200 \mu \mathrm{M})$, administered at the end of the experiment. The first curve, determined in the absence of any antagonist, is shown by filled circles. In a, the second curve (open circles) and third curve (open squares) curves were determined in the presence of $200 \mathrm{nM}(-)$-propranolol incubated for $45 \mathrm{~min}$ before the second curve was begun. This demonstrates that force responses of field stimulation are due to interaction with $\beta_{1}$-adrenoceptors of neuronally released noradrenaline. $\mathbf{b}$ The

noradrenaline and adrenaline through $\beta_{1}$ - and $\beta_{2}$-adrenoceptors respectively (Kaumann and Sanders 1993, 1994). We know that $\beta_{1}$ - and $\beta_{2}$-adrenoceptors produce a similar incidence of arrhythmias in human atrium, despite the lower $\beta_{2^{-}}$ adrenoceptor density, probably because $\beta_{2}$-adrenoceptors are selectively coupled to Gs protein compared to $\beta_{1}$-adrenoceptors (Kaumann and Sanders 1993; Kaumann et al. 1995a). It is still remarkable that 5-HT can elicit arrhythmias in human atrium because the density of $5-\mathrm{HT}_{4}$ receptors is at least 10 fold and 5-fold lower than the density of $\beta_{1}$ - and $\beta_{2}$-adrenoceptors respectively (Kaumann et al. 1996). The author has b
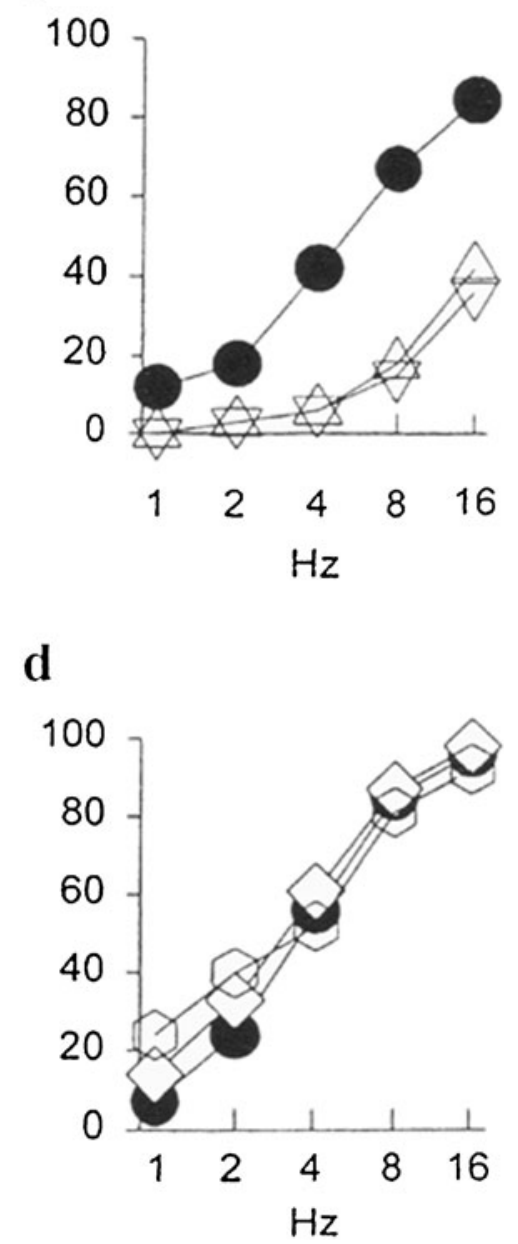

second and third curves were carried out in the presence of (-)-propranolol, but the tissues were incubated for $30 \mathrm{~min}$ with $10 \mu \mathrm{M}$ 5-HT followed by a $10 \mathrm{~min}$ wash-out period before the determination of the second (open triangles) and third curves (inverted open triangles). The protocol of the experiment in $\mathbf{c}$ was as in $\mathbf{b}$, except that the $5-\mathrm{HT}_{4}$ receptor antagonist SB-207710 $(100 \mathrm{nM})$ was added after the second curve (filled diamonds). In d, no 5-HT was administered. The second curve (open diamonds) and third curve (open hexagons) were determined in the absence and presence of SB-207710 respectively. The hatched area in $\mathbf{c}$ represents the increase in force elicited from neuronally captured and release 5-HT interacting with $5-\mathrm{HT}_{4}$ receptors. For further details see Kaumann (2000)

always suspected that the mechanisms of arrhythmia production by 5-HT differs from that of catecholamines, despite the coupling of the 3 receptors to Gs protein. The situation with porcine atrial $5-\mathrm{HT}_{4}$ receptors is even more puzzling with a density of only 0.34 fmol. $\mathrm{mg}^{-1}$, approximately 300 -fold and 30 -fold lower than the densities of $\beta_{1}$ - and $\beta_{2}$-adrenoceptors respectively (Kaumann et al. 1995b) and yet apparently capable of mediating atrial arrhythmias (Rahme et al. 1999). The interesting findings of Gergs et al. in their TG mouse that only $5-\mathrm{HT}_{4}$ receptors, but hardly $\beta$-adrenoceptors, mediate spontaneous arrhyhmias, suggest peculiar mechanisms for $5-\mathrm{HT}_{4}$ 
receptors to induce arrhythymias. These mechanisms are still unknown, but appear different for mechanisms for $\beta$ adrenoceptor-mediated arrhythmias, at least in the TG mouse. But in human atrium the incidence of arrhythmias is higher through $\beta$-adrenoceptors than through 5 - $\mathrm{HT}_{4}$ receptors, while the opposite occurs in TG mice. The significance of this notorious difference for human atrial arrhythmias is presently unknown.

\section{References}

Birkeland JAK, Sjaastad I, Brattelid T, Qvigstad E, Moberg ER, Krobert KA, Bjørnerheim R, Skomedal T, Sejersted OM, Osnes J-B, Levy FO (2006) Effects of treatment with a 5-HT4 receptor antagonist in heart failure. Br J Pharmacol 150:143-152

Brattelid T, Qvigstad E, Lynham JA, Molenaar P, Aas H, Geiran O, Skomedal T, Osnes JB, Levy FO, Kaumann AJ (2004) Functional serotonin $5-\mathrm{HT}_{4}$ receptors in porcine and human ventricular myocardium with increased 5- $\mathrm{HT}_{4} \mathrm{mRNA}$ in heart failure. NaunynSchmiedeberg's Arch Pharmacol 370:157-166

Brattelid T, Qvigstad E, Moltzau LR, Bekkevold SV, Sandnes DL, Birkeland JA, Skomedal T, Osnes JB, Sjaastad I, Levy FO (2012) The cardiac ventricular $5-\mathrm{HT}_{4}$ receptor is functional in late foetal development and is reactivated in heart failure. PLoS One 7(9): e45489. doi: 10.1371

Côté F, Thévenot E, Fligny C, Fromes Y, Darmon M, Ripoche MA, Bayard E, Hanoun N, Saurini F, Lechat P, Dandolo L, Hamon M, Mallet J, Vojdani G (2003) Disruption of the non-neuronal tph 1 gene demonstrates the importance of peripheral serotonin in cardiac function. Proc Natl Acad Sci U S A 100:13525-13530

Gergs U, Neumann J, Simm A, Silber R-E, Remmers FO, Läer S (2009) Phosphorylation of phospholamban and troponin I through 5-HT4 receptors in the isolated human atrium. NaunynSchmiedeberg's Arch Pharmacol 379:349-359

Gergs U, Baumann M, Böckler A, Buchwalow IB, Ebelt H, Fabritz L, Hauptmann S, Keller N, Kirchhof P, Klöckner U, Pönicke K, Rueckschloss U, Schmitz W, Werner F, Neumann J (2010) Cardiac overexpression of the human $5-\mathrm{HT}_{4}$ receptor in mice. Am J Physiol Heart Circ Physiol 299:H788-H798

Gergs U, Böckler A, Ebelt H, Hauptmann S, Keller N, Volker O, Pönicke K, Schmitz W, Neumann J (2013) Human 5-HT 4 receptor stimulation in atria of transgenic mice. Naunyn-Schmiedeberg's Arch Pharmacol (In press)

Kaumann AJ (1990) Piglet sinoatrial 5-HT receptors resemble human atrial 5-HT 4 -like receptors. Naunyn-Schmiedeberg's Arch Pharmacol 342:619-622

Kaumann AJ (1994) Do human 5-HT 4 receptors mediate arrhythmias? Trends Pharmacol Sci 15:451-455

Kaumann AJ (2000) $\mathrm{G}_{\mathrm{s}}$ protein-coupled receptors in human heart. In: Kenakin T, Angus JA (eds) Handbook of Experimental Pharmacology, vol 148 (Figure 10a-d, page 106). The Pharmacology of functional, biochemical and recombinant receptor systems. Springer, Berlin, Heidelberg, pp 73-116

Kaumann AJ, Levy FO (2006) 5-Hydroxytryptamine receptors in the human cardiovascular system. Pharmacol Ther 111:674-706

Kaumann AJ, Sanders L (1993) Both $\beta_{1}$ - and $\beta_{2}$-adrenoceptors mediate catecholamine-evoked arrhythmias in isolated human right atrium. Naunyn-Schmiedebergs Arch Pharmacol 348:536-540

Kaumann AJ, Sanders L (1994) 5-hydroxytryptamine causes ratedependent arrhythmias in isolated human atrium. NaunynSchmiedeberg's Arch Pharmacol 349:331-337
Kaumann AJ, Sanders L, Brown AM, Murray KJ, Brown MJ (1990) A 5 hydroxytryptamine receptor in human atrium. Br J Pharmacol 110:879-885

Kaumann AJ, Lynham J, Sanders L, Brown AM, Molenaar P (1995a) Contribution of differential efficacy to the pharmacology of human $\beta_{1}$ - and $\beta_{2}$-adrenoceptors. Pharmacol Commun 6:215-222

Kaumann AJ, Lynham JA, Brown AM (1995b) Labelling with $\left[{ }^{125} \mathrm{I}\right]$ SB 207710 of a small $5-\mathrm{HT}_{4}$ receptor population in piglet right atrium: functional relevance. Br J Pharmacol 115:933-936

Kaumann AJ, Lynham JA, Brown AM (1996) Comparison of the densities of $5-\mathrm{HT}_{4}$ receptors, $\beta_{1}$ - and $\beta_{2}$-adrenoceptors in human atrium: functional implications. Naunyn Schmiedeberg's Arch Pharmacol 353:592-595

Kjekshus JK, Torp-Pedersen C, Gullestad L, Køber L, Edvardsen T, Olsen IC, Sjaastad I, Qvigstad E, Skomedal T, Osnes J-B, Levy FO (2009) Effect of piboserod, a 5- $\mathrm{HT}_{4}$ serotonin receptor antagonist, on left ventricular function in patients with symptomatic heart failure. Eur Heart J 11:771-778

Neef S, Dybkova N, Sossalla S, Ort KR, Fluschnik N, Neumann K, Seipelt R, Schöndube A, Hasenfuss G, Maier L (2010) CaMKIIdependent diastolic SR $\mathrm{Ca}^{2+}$ leak and elevated diastolic $\mathrm{Ca}^{2+}$ levels in right atrial myocardium of patients with atrial fibrillation. Circ Res 106:1134-1144

Ouadid H, Seguin J, Dumuis A, Bockaert J, Nargeot J (1992) Serotonin increases calcium current in human atrial myocytes via the newly described 5-hydroxytryptamine4 receptors. Mol Pharmacol 41:346-351

Parker S, Taylor EM, Hamburger SA, Vimal M, Kaumann AJ (1994) Blockade of human and porcine myocardial 5-HT4 receptors by SB203186. Naunyn-Schmiedeberg's Arch Pharmacol 335:28-35

Pau D, Workman AJ, Kane KA, Rankin AC (2003) Electrophysiological effects of 5-hydroxytryptamine on isolated human atrial myocytes and the influence of chronic $\beta$-adrenoceptor blockade. Br J Pharmacol 140:1434-1441

Pau D, Workman AJ, Kane AK, Rankin AC (2007) Electrophysiological and arrhythmogenic effects of 5-hydroxytryptamine on human atrial cells are reduced in atrial fibrillation. J Mol Cell Cardiol 42:54-62

Pönicke K, Gergs U, Buchwalow IB, Hauptmann S, Neumann J (2012) On the presence of serotonin in mammalian cardiomyocytes. Mol Cell Biochem 365:301-312

Qvigstad E, Brattelid T, Sjaastad I, Andressen KW, Krobert KA, Birkeland JA, Sejersted OM, Kaumann AJ, Skomedal T, Osnes JB, Levy FO (2005) Appearance of a ventricular 5- $\mathrm{HT}_{4}$ receptormediated inotropic response to serotonin in heart failure. Cardiovasc Res 65:869-878

Rahme MM, Cotter B, Leistad E, Wadhwa MK, Mohabir R, Ford AP, Eglen RM, Feld GK (1999) Electrophysiological and antiarrhythmic effects of the atrial selective 5-HT(4) receptor antagonist RS100302 in experimental atrial flutter and fibrillation. Circulation 100:2010-2017

Sanders L, Kaumann AJ (1992) A 5-HT - -like receptor in human left atrium. Naunyn-Schmiedeberg's Arch Pharmacol 345:382-386

Sanders L, Lynham JA, Bond B, DelMonte F, Harding S, Kaumann AJ (1995) Sensitization of human atrial 5-HT4 receptors by chronic $\beta$-blocker treatment. Circulation 92:2526-2539

Singh S, Johnson PI, Javed A, Gray TS, Lonchyna VA, Wurster RD (1999) Monoamine- and histamine-synthesizing enzymes and neurotransmitters within neurons of adult cardiac ganglia. Circulation 99:411-419

Sole MJ, Shum A, VanLoon GR (1979) Serotonin: metabolism in the normal and failing hamster heart. Circ Res 45:629-634

Vilaró MT, Doménech T, Palacios JM, Mengod G (2002) Cloning and characterization of a novel human $5-\mathrm{HT}_{4}$ receptor variant that lacks alternatively spliced carboxyl terminal exon. RT-PCR distribution in human brain and periphery of multiple $5-\mathrm{HT}_{4}$ receptor variants. Neuropharmacology 42:60-73 